\title{
West Greenland's Cod-to-Shrimp Transition: Local Dimensions of Climatic Change
}

\author{
LAWRENCE C. HAMILTON, ${ }^{1,2}$ BENJAMIN C. BROWN ${ }^{1}$ and RASMUS OLE RASMUSSEN ${ }^{3}$
}

(Received 9 April 2002; accepted in revised form 2 January 2003)

\begin{abstract}
West Greenland's transition from a cod-fishing to a shrimp-fishing economy, ca. 1960-90, provides a case study in the human dimensions of climatic change. Physical, biological, and social systems interacted in complex ways to affect coastal communities. For this integrated case study, we examine linkages between atmospheric conditions (including the North Atlantic Oscillation), ocean circulation, ecosystem conditions, fishery activities, and the livelihoods and population changes of two West Greenland towns: Sisimiut, south of Disko Bay, and Paamiut, on the southwest coast. Sisimiut prospered as a fishing center through the cod-to-shrimp transition. Paamiut, more specialized in cod fishing, declined. Their stories suggest two general propositions about the human dimensions of climatic change. First, socially important environmental changes result not simply from climatic change, but from interactions between climate, ecosystem, and resource usage. Second, environmental changes affect people differentially and through interactions with social factors. Social networks and cohesion (social capital) are important, in addition to skills (human capital), investments (physical capital), and alternative resources (natural capital): all shape how the benefits and costs are distributed.
\end{abstract}

Key words: Greenland, fisheries, climatic change, human dimensions, Sisimiut, Paamiut, Elias Kleist, North Atlantic Oscillation, Great Salinity Anomaly, Unaami

RÉSUMÉ. Dans l'ouest du Groenland, la transition de l'économie morutière à l'économie crevettière, qui s'est effectuée à peu près de 1960 à 1990, offre une étude de cas pour la dimension humaine du changement climatique. Des interactions complexes entre les systèmes physique, biologique et social ont eu des répercussions sur les communautés côtières. Pour cette étude de cas intégrée, on examine les liens entre les conditions atmosphériques (y compris l'oscillation nord-atlantique), la circulation océanique, les conditions de l'écosystème, les activités de pêche ainsi que les changements dans le mode de subsistance et la démographie de deux villes du Groenland occidental: Sisimiut, au sud de la baie de Disko, et Paamiut, sur la côte sud-ouest. Durant la transition de la morue à la crevette, Sisimiut a prospéré en tant que centre de pêche, alors que Paamiut, plus spécialisée dans la pêche de la morue, a connu un déclin. Ces deux histoires nous permettent de formuler deux hypothèses majeures sur la dimension humaine du changement climatique. Tout d'abord, les modifications de l'environnement qui sont importantes sur le plan social ne résultent pas seulement du changement climatique, mais des interactions entre le climat, l'écosystème et l'utilisation des ressources. Deuxièmement, les modifications de l'environnement affectent les gens différemment et par le biais d'interactions avec des facteurs sociaux. La cohésion et les systèmes sociaux (capital social) sont importants, parallèlement aux compétences (capital humain), aux investissements (capital physique) et aux ressources de remplacement (capital naturel): ils définissent tous la façon dont sont répartis les coûts et les avantages.

Mots clés: Groenland, pêches, changement climatique, dimensions humaines, Sisimiut, Paamiut, Elias Kleist, oscillation nordatlantique, grande anomalie de salinité, Unaami

Traduit pour la revue Arctic par Nésida Loyer.

\section{INTRODUCTION}

The rise and fall of West Greenland's cod fishery during 1920-90 reflects interactions between climate, ecosystem, and society. This fishery arose around 1920, as warming currents brought in Atlantic cod (Gadus morhua) and allowed spawning in the waters off southwest Greenland. At about this same time, warming also contributed to the decline of seal hunting, which had been Greenlanders' traditional livelihood. Cod fishing subsequently became a mainstay of the Greenland economy, the focus of much infrastructure and planning (Mattox, 1973; Rasmussen and Hamilton, 2001). The cod fishery declined steeply in the 1960s, however, as waters cooled again (Buch and Hansen, 1988; Vilhjálmsson, 1997; Borovkov and Stein, 2001; Buch et al., 2001). Although climatic change influenced both the rise and the fall of cod fishing, it did so through interactions with human resource use. Overhunting across the northern Atlantic contributed to the earlier decline of sealing (Mattox, 1973). In a parallel fashion,

\footnotetext{
${ }^{1}$ Sociology Department, University of New Hampshire, Durham, New Hampshire 03824, U.S.A.

${ }^{2}$ Corresponding author: Lawrence.Hamilton@unh.edu

${ }^{3}$ North Atlantic Regional Studies, Department of Geography and International Development Studies, Roskilde University, 4000 Roskilde, Denmark

(C) The Arctic Institute of North America
} 


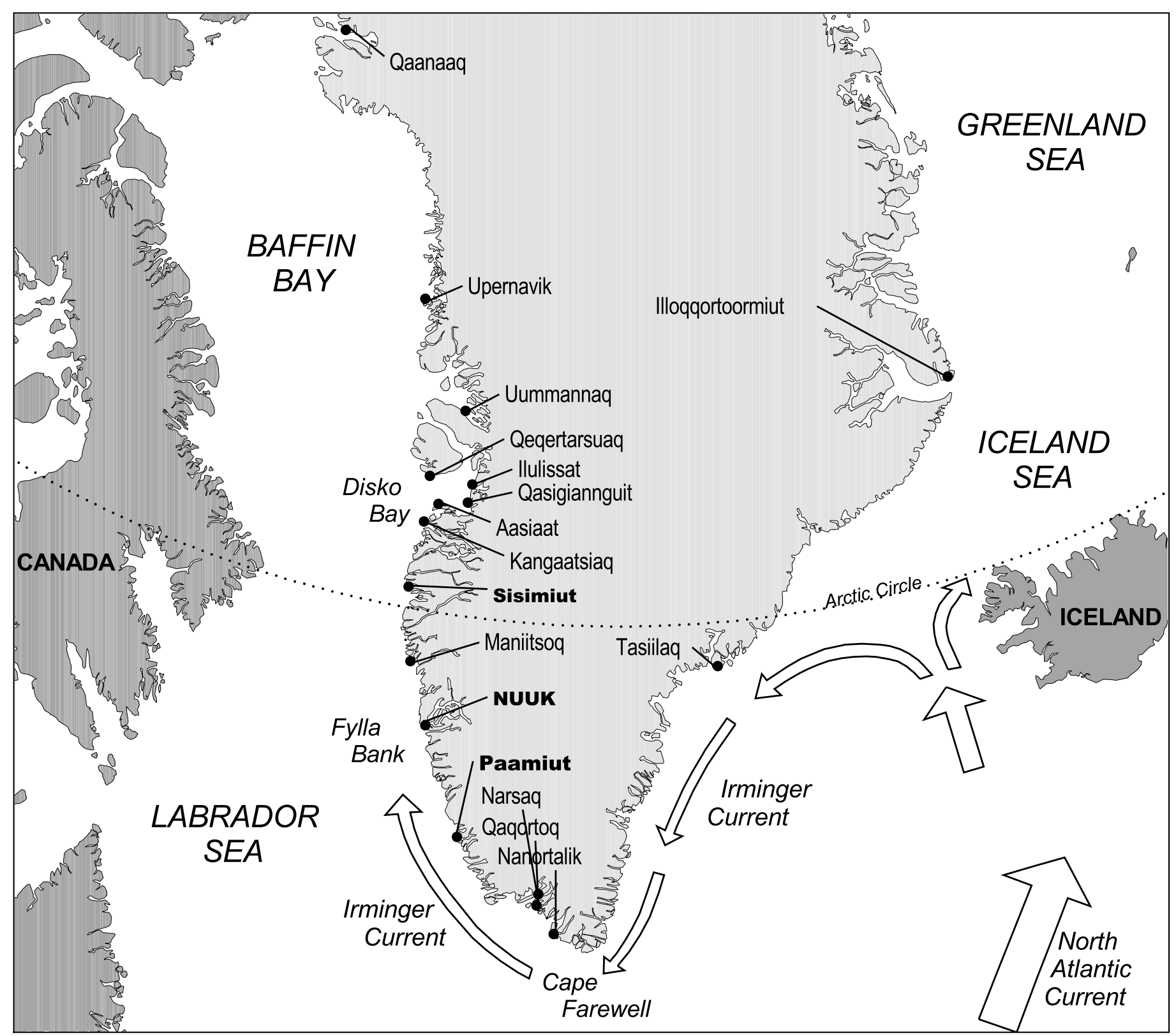

FIG. 1. Map of Greenland.

decades later, overfishing helped drive down the cod stocks (Rätz, 1992, 1999). Social factors filtered the consequences of both transitions for Greenlanders who depend upon marine resources (Mattox, 1973; Marquardt et al., 1999; Rasmussen and Hamilton, 2001).

The northern Atlantic is physically dynamic, a turning point for global ocean circulation that is implicated in rapid prehistoric (and possible future) climatic shifts (Mayewski et al., 1994; Manabe, 1995; Broecker, 1997; Ganopolski and Rahmstorf, 2000; Blunier and Brook, 2001). Some analyses suggest that greenhouse-induced global change might be manifest through amplification of a longstanding pattern of variation called the North Atlantic Oscillation (NAO), which in recent years has attained historically unprecedented highs, associated with widespread climatic changes in the Northern Hemisphere (Hurrell and Van
Loon, 1997; Langenberg, 2000; Serreze et al., 2000; Hurrell et al., 2001). Air pressure variations that characterize the NAO (and the related Arctic Oscillation, or AO) affect wind and sea conditions around Greenland, and hence also the ecosystems that those seas contain (Jakobsson et al., 1994; Dickson et al., 1996; Vilhjálmsson, 1997; Buch et al., 2001; Turrell and Holliday, 2001).

Northern Atlantic ecosystems have shown recent volatility. Cod and other demersal fish, keystone predators, exhibited declines that led to fishery crises during the 1980s and 1990s - not only off Greenland, but also in New England, eastern Canada, Iceland, the Faroe Islands, Norway, and northwestern Russia (Arnason and Felt, 1995; Hannesson, 1996; Boreman et al., 1997). As predatory groundfish became less abundant, commercially significant increases were often observed in populations of 


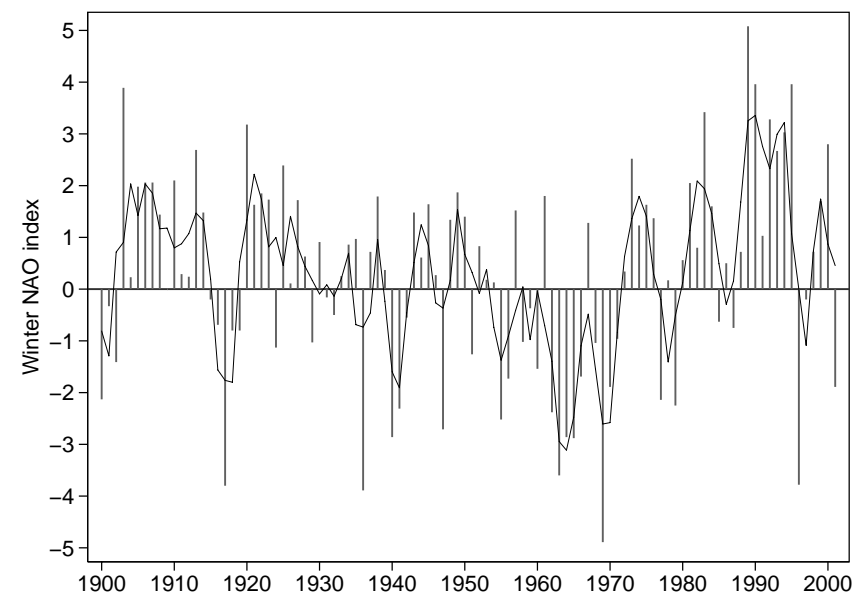

FIG. 2. Lisbon-Iceland winter (December through March) North Atlantic Oscillation index, 1900-2001. Data described in Hurrell (1995).

invertebrates, notably shrimp, crab, and lobster. Fisheries necessarily adapt to changing resources, but these adaptations require social changes on land (Hamilton and Haedrich, 1999; Hamilton and Butler, 2001).

In the case of West Greenland, climatic variation and fishing pressure together caused an ecological shift that transformed the livelihoods of fishing folk and communities. As the cod fishery vanished, it was replaced economically by rising fisheries for shrimp (Pandalus borealis) and Greenland halibut (Reinhardtius hippoglossoides) (Hvingel, 1999a; Hamilton et al., 2000). In this paper we follow a series of links connecting large-scale atmospheric variations to local ocean conditions, ecosystem, fisheries, and coastal communities during Greenland's cod-to-shrimp transition. Transient natural advantages of certain West Greenland settlements (Fig. 1), interacting with social forces, formed the local dimensions of climatic change.

\section{THE NAO AND WEST GREENLAND CLIMATE}

The North Atlantic Oscillation (NAO) refers to a largescale alternation of atmospheric mass between the Icelandic Low and the Azores High pressure centers, most pronounced in wintertime (Hurrell, 1995; Dickson et al., 1996). Together with the better-known El Niño/Southern Oscillation (ENSO), the NAO explains much of the interannual variability in worldwide weather and climate (Hurrell and van Loon, 1997). Calculations based on differences between historical air-pressure measurements from Lisbon, Portugal, (or alternatively, the Azores or Gibraltar) and Stykkishólmur, Iceland, yield an NAO index extending back into the 19th century (Hurrell, 1995). Analyses of ice cores, tree rings, and other proxies have found long-term evidence of decadal-scale climatic cycles around the North Atlantic, although their relationship to the modern NAO remains problematic (Schmutz et al., 2000).

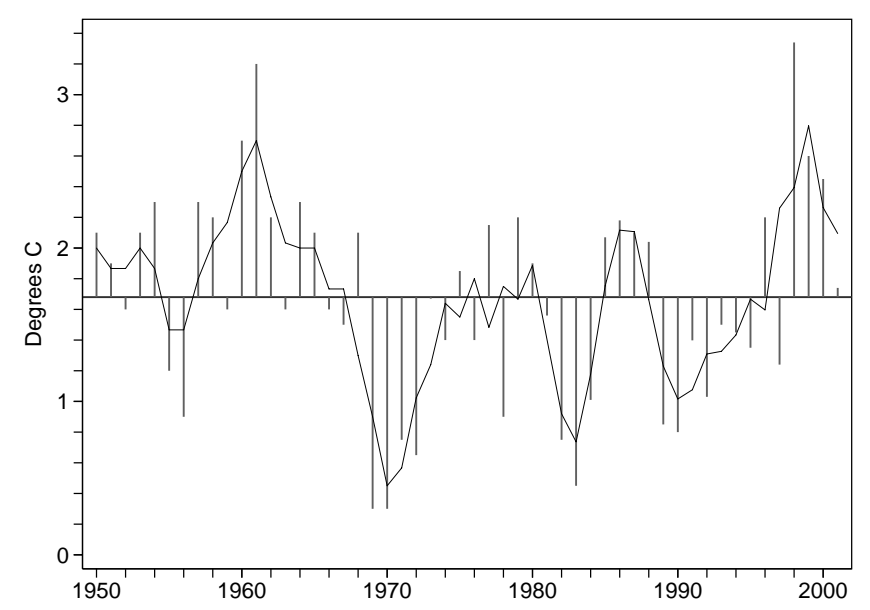

FIG. 3. Mid-June water temperatures at $0-40 \mathrm{~m}$ on top of Fylla Bank, west of Nuuk, 1950-2001. Data described in Buch (2000a, b).

Positive or high-NAO conditions classically involve a low-pressure anomaly centered on Greenland, with a zonal high-pressure anomaly across the Atlantic to its south, and strong westerly winds in between. Surface winds tend to be northerly over Greenland and eastern Canada, bringing down cold Arctic air. Conversely, negative or low-NAO conditions involve higher pressure over Greenland and lower pressure to the south. Surface winds tend to be southerly and air temperatures warmer over Greenland and eastern Canada. Figure 2 graphs the Lisbon-Iceland winter NAO index over 1900-2001. NAO index values in Figure 2 reflect the difference of normalized (relative to 1864-1983) sea level pressures between Lisbon, Portugal, and Stykkishólmur/Reykjavík, Iceland, averaged for the months of December through March. These data cover winters from 1899-1900 through 2000-01. Also shown are the three-year running means. The most extreme and persistent negative phase occurred during the 1950s and 1960s. After 1970, NAO behavior shifted into a cyclical, persistent, and extreme positive phase. Anomalous negative conditions interrupted this positive phase in the winters of 1995-96 and 2000-01.

Sea and air temperatures around West Greenland respond to changes in the NAO, but not in a simple, consistent way. Figure 3 graphs mid-June sea temperatures $(0-40 \mathrm{~m})$ on Fylla Bank, west of Nuuk. Above-average temperatures in the 1960s occurred during the negative NAO phase. Warm, Atlantic-origin Irminger Current water (mixed with colder local water) often extended from Cape Farewell up the west coast to Fylla Bank or beyond. The coldest event in this series indicates the arrival in 1969-70 of the Great Salinity Anomaly, which originated as a pulse of Arctic ice and water blown out through Fram Strait during the negative-NAO conditions of the 1960s (Dickson et al., 1988; Belkin et al., 1998; Hilmer et al., 1998). Belkin (2000) reviews evidence that discharge from the Greenland Ice Sheet also contributed to Atlantic salinity anomalies of the 1970s, 1980s, and 1990s. Ice 


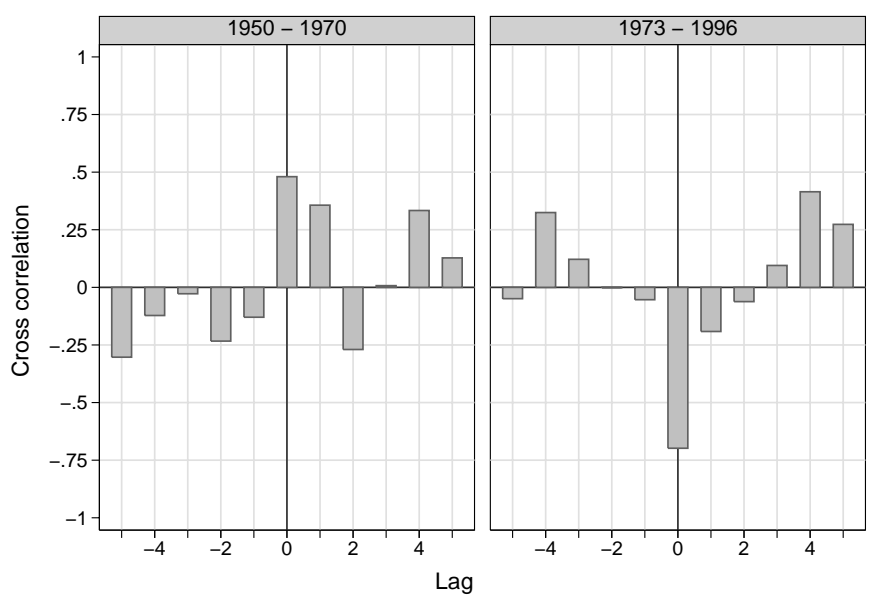

FIG. 4. Cross-correlation functions of winter NAO and Fylla Bank temperatures during low-NAO (1950-70, left) and high-NAO (1973-96, right). The +1 lag correlation, for example, describes the relationship between winter NAO at the start of year $t$ and summer temperature in year $t+1$.

sheet attrition appears to have accelerated recently, making its contribution more significant in the 1990s.

The second-coldest spike in Figure 3 reflects the arrival in the early 1980 s of another temperature/salinity anomaly (termed GSA ' 80 s, in contrast to the previous GSA '70s) that did not originate through distant Fram Strait, but was formed locally in the Labrador Sea/Baffin Bay, with contributions from Arctic freshwater outflow through the Canadian Arctic Archipelago. The winters of 1982-84 brought the coldest air temperatures ever recorded in Nuuk or Aasiaat (Disko Bay), along with correspondingly severe sea ice conditions offshore. Both this local cooling and the outflow of Arctic water were driven by strong northerly winds of the positive NAO phase (Belkin et al., 1998).

After 1970, the Arctic/North Atlantic climate system changed in many respects (Hurrell and van Loon, 1997; Serreze et al., 2000; Morison et al., 2000, 2001). Morison et al. (2001) refer to the Arctic changes collectively as Unaami, a Yupik word for "tomorrow." Local manifestations of these system changes included shifts in atmosphere-ocean interactions off West Greenland (Buch et al., 2001). Figure 4 contrasts the cross-correlations between NAO and Fylla Bank temperature during low-NAO (1950 $70)$ and high-NAO (1973-96) phases. Same-year correlations are positive $(r=+0.48)$ during $1950-70$, indicating that higher-NAO years tended to have warmer sea temperatures (relative to 1950-70 means). But same-year cross-correlations become stronger and negative $(\mathrm{r}=$ -0.70 ) during $1973-96$, indicating that higher-NAO years coincided with lower sea temperatures. The 1950-70 relationship exhibits more "memory," in that the correlation between NAO and temperature the following year $(\mathrm{r}=+0.36$ at the $+1 \mathrm{lag})$ remains significant. During the 1973-96 period, however, there is little correlation between NAO and following-year temperature. Buch et al. (2001) observe that after 1970, positive NAO conditions moved the Atlantic Current eastward so that its offshoot, the Irminger Current, had less effect on West Greenland. Pure Irminger water no longer reached even Cape Farewell, and Irminger Mode (Irminger mixed with local) water became scarce at more northerly Fylla Bank. Consequently, during this period NAO fluctuations affected West Greenland temperatures directly (and more or less immediately) through local atmospheric conditions, rather than by driving the long-distance movements of water mass, as had previously been the case.

\section{COD TO SHRIMP}

The rise and fall of West Greenland's cod fishery has been widely noted as an instance of climatic change affecting modern human affairs (e.g., Mattox, 1973; Buch and Hansen, 1988; Vilhjálmsson, 1997; Hamilton et al., 2000). When Irminger water flowed northwards along the SW coast of Greenland after 1917, it carried Atlantic cod from their main spawning grounds west of Iceland, and intermittently created favorable conditions for local West Greenland spawning as well. This new fishery resource became the focus of development for Greenland's economy and infrastructure, including the distribution of settlements. Like other Atlantic cod populations, the West Greenland stocks came under heavy fishing pressure from an international fleet after World War II. Total catches exceeded 400000 metric tons as cod from favorable spawning years matured: this occurred in 1962-63, for the 1956-57 year class, and in 1967, for the 1960-61 year class (Smidt, 1989). With such huge removals and declining conditions, however, catches dropped below 100000 metric tons a few years later and never regained a high level (Fig. 5). By 1992, West Greenland's cod were essentially gone.

Overfishing played a central role in their demise, as it did in other Atlantic cod fisheries (Rätz, 1992, 1999). Fishing pressure interacted with climatic events, however. The cold Arctic water of GSA '70s created unfavorable conditions for spawning in the late 1960s, while trawler fleets were rapidly consuming mature stock. Since older cod tend to be individually and reproductively more robust, fishery removals were actually increasing the stock's vulnerability to climatic variation. Inflows of warm Irminger water declined after 1970, so that few young cod drifted in from Iceland. The current returned briefly in 1984 , and cod arriving in that year subsequently matured to supply one last spike for the fishery in 1988-90. But ultimately the combination of overfishing, water too cold for spawning, and lack of outside recruitment proved fatal to West Greenland stocks. In the late 1990s, atmospheric conditions warmed sea temperatures back up to their early-1960s levels. But there were no cod left to spawn, and the Irminger Current no longer flowed northwards bringing new recruits.

As Greenland's cod fishery collapsed, an expanding fishery for northern shrimp (Pandalus borealis) took its eco- 


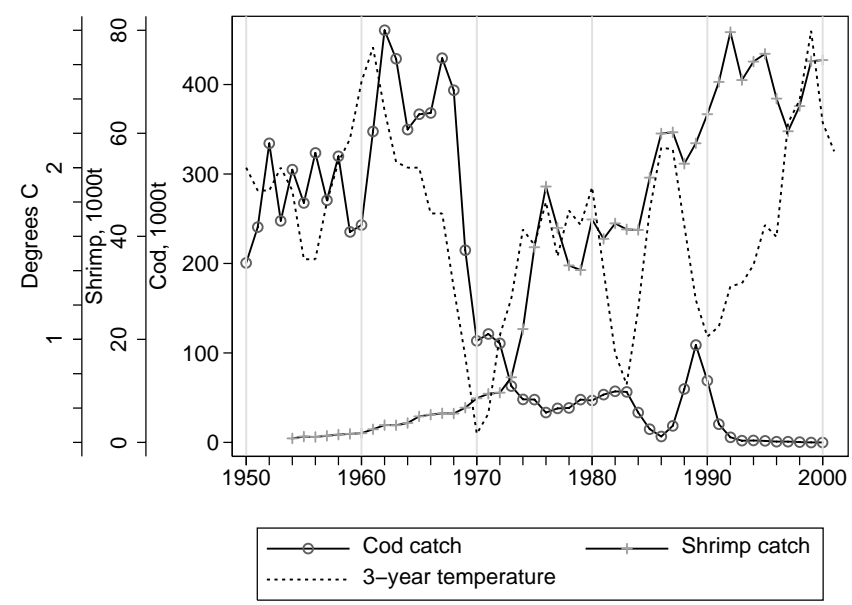

FIG. 5. Fylla Bank temperature (three-year running means) shown with total catches of Atlantic cod and northern shrimp off West Greenland during 1950 2000. Vertical axis rescaled for temperature $\left(0.4-2.8^{\circ} \mathrm{C}\right)$, cod catch (0-461 000 metric tons), and shrimp catch (0-80 000 metric tons). Catch data from Horsted (2000), Siegstad (2000), and NAFO (2002).

nomic place. Figure 5 shows total West Greenland (NAFO subarea 1) catches of shrimp, primarily by Greenlandic vessels, increasing from about 10000 metric tons in 1972 to more than 70000 metric tons in the 1990s. Shrimp catches reached a maximum near 80000 metric tons in 1992, and subsequently varied around somewhat lower levels. Greenlandic vessels also dominate the smaller East Greenland shrimp fishery, where catches ranged from 3000 to 7000 metric tons during the 1990s (Hvingel, 1999b). Shrimp became Greenland's chief export, accounting for over $70 \%$ of total export value during 1992-99 (Statistics Greenland, 2000). Although shrimp replaced cod economically, its benefits have been distributed differently within Greenland society (Hamilton et al., 2000; Rasmussen and Hamilton, 2001).

Figure 5 depicts an economic transition, from cod fishing to shrimp fishing. The fishery changed because its underlying ecosystem had shifted from one dominated by predatory finfish to one in which top predators (not only cod, but other demersal fish; see Rätz, 1999) became scarce, and a zooplankton-eating invertebrate (shrimp) became more common. That ecological change follows worldwide patterns of "fishing down food webs" described by Pauly et al. (1998) (also see Jackson et al., 2001). Figure 6 shows biomass trends for cod and shrimp. Although this graph must be interpreted with caution, it is consistent with the hypothesis that the codfish collapse removed a predatory constraint on shrimp populations. The cod and shrimp surveys employed different sampling methods and geographical coverage, so they are not strictly comparable. Moreover, there are inevitably large uncertainties in biomass estimates. Uncertainties in the Greenland shrimp survey results have been quantified, as shown in Figure 6 (based on Carlsson and Kanneworff, 2000). Unfortunately, we have limited information about shrimp abundance before these surveys began in 1988. Efforts to fill this gap using catch-per-unit-effort (CPUE) calcula-

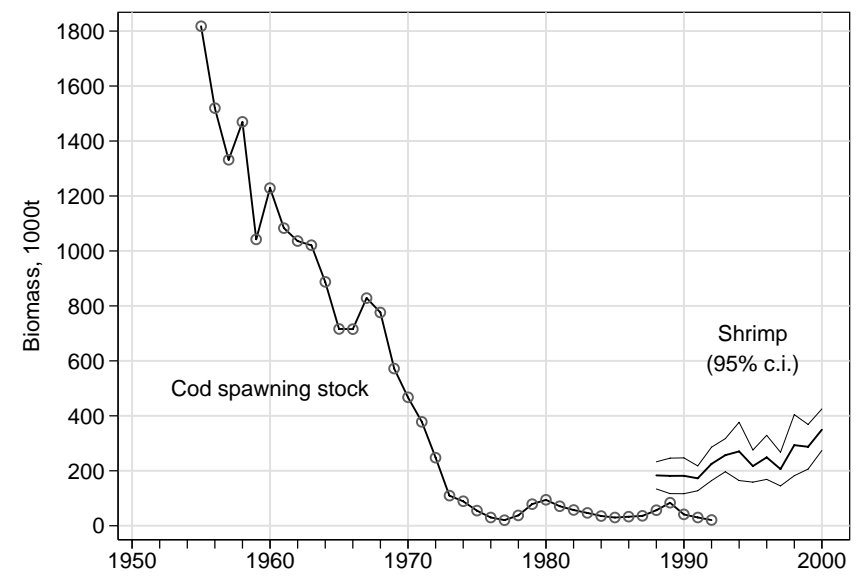

FIG. 6. Trends in cod spawning biomass (Rätz, 1992) and shrimp biomass (Carlsson and Kanneworff, 2000) off West Greenland, 1955-2000. Approximate $95 \%$ confidence intervals ( \pm 2 standard errors) shown with shrimp biomass estimates.

tions yield estimates that vary wildly from year to year (Hvingel et al., 2000). CPUE interpretations are complicated by the increasing efficiency of trawling, as well as by the fact that the early shrimp fishery was concentrated in Disko Bay.

Cod-shrimp relationships are not well studied off West Greenland. Research on their counterparts in the Barents Sea, however, suggests that the cod there control the shrimp population (Berenboim et al., 2000). A recent meta-analysis by Worm and Myers (2003) found that most of the available North Atlantic biomass time series are consistent with the predator-control (top-down) hypothesis. They also note interactions with temperature. Newfoundland provides other salient examples: crustaceans (snow crab, Chionoecetes opilio, as well as northern shrimp) became more abundant as the cod disappeared (Hamilton and Butler, 2001). We suspect that a similar dynamic occurs off Greenland, where snow crab catches have also increased recently (NAFO, 2002).

Greenland's earliest shrimp fishery centered on Disko Bay. It gradually expanded as fishable stocks were found farther south. Fishery expansion probably tracked an expanding shrimp distribution, as cod thinned out and vanished from the south. But this effect was confounded by technological innovations (for example, rockhopper gear) that opened new areas to exploitation. Figure 7 maps the known biomass of northern shrimp off West Greenland in 1988, when the modern shrimp survey began, and in 2000. For simplicity just three settlements - Sisimiut, Paamiut, and the capital city of Nuuk - are marked on these maps. In the 1980s, the major known resource centered on Sisimiut and points north. (Smaller concentrations also existed in the fjords of the Julianehåb Bay in South Greenland, which were not covered by the survey.) Starting in the early 1990s, increasing offshore shrimp concentrations were discovered south of Nuuk and down towards Paamiut. The next section considers how these marine changes were felt on land. 

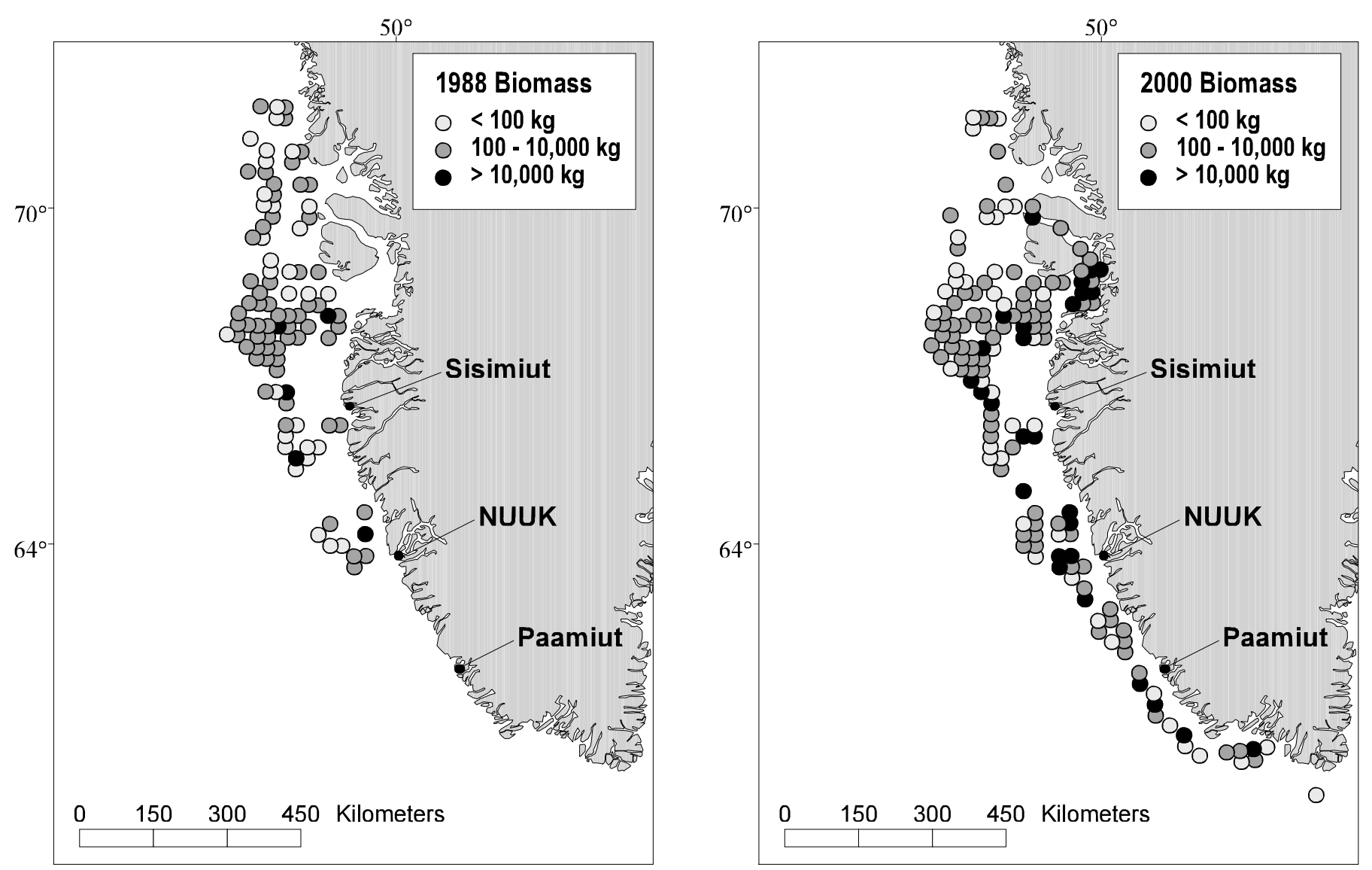

FIG. 7. Estimated northern shrimp biomass (mean kg/km² swept) in West Greenland waters, 1988 (left) and 2000 (right). Each circle represents the mean for any trawls within a $1 / 5^{\circ}$ latitude $\times 1 / 2^{\circ}$ longitude cell. Raw data from the Greenland Natural Resources Institute (Grønlands Naturinstitut); see Carlsson and Kanneworff (2000).

\section{A TALE OF TWO CITIES}

Two West Greenland municipalities marked in Figure 7, Paamiut and Sisimiut, followed contrasting paths during the cod-to-shrimp transition. Paamiut had been developed as a cod fishing center, but lost its main resource with the codfish collapse and subsequently saw its human population decline because of out-migration. Sisimiut, $500 \mathrm{~km}$ farther north, was less specialized. Its fishermen pursued multiple species, including shrimp. As cod faded and shrimp became the dominant catch, Sisimiut grew rapidly (Hamilton et al., 2000; Rasmussen and Hamilton, 2001).

Commercial fishing started at Ilulissat and other settlements in the late 1800s, reaching Sisimiut around 1910 (Rasmussen and Hamilton, 2001). Initiatives came at first from outsiders, notably fishery research vessels and trading post managers, although Greenlanders did inshore catching and processing work, often using their own equipment. Greenlandic initiatives at Sisimiut, beginning in the 1920s, marked a new stage of development.

Nathan Larsen of the Sisimiut Museum has compiled archives, correspondence, and oral histories about Sisimiut. Some of this historical material is presented in his forthcoming book, Arfaggikkutta Taperumaaipoq ('When we catch more whales, we will give more'). The title refers to a letter written in 1771 by Sisimiut people to the King of Denmark, asking him to build them a church. They sent along the profits from four whales, and promised that when they caught more whales, they would send more money. The church was built around 1774, and stands today next to the Sisimiut Museum. Nowadays, "When we catch more whales..." has become an expression repeated when presenting a gift. This story resonates with the observations about Sisimiut and social capital in our Discussion.

Larsen's next book (tentatively entitled Nakuak) will concentrate on the emergence of a Greenlandic fishery in Sisimiut. Atlantic halibut (helleflynder, Hippoglossus hippoglossus) provided a subsistence resource known from pre-colonial times. (Today, the smaller Greenland halibut (hellefisk, Reinhardtius hippoglossoides) is Greenland's second most valuable catch after shrimp.) Danes began fishing halibut commercially in this area around 1910, and taught local men the trade (Smidt, 1989). A canning factory, representing an advance over earlier salting methods, came to Sisimiut in 1924. In 1928, Sisimiut resident Elias Kleist and five partners pooled resources and became the first Greenlanders to purchase their own fishing vessel, the 36-foot Nakuak ('strong'). Their enterprise was 
successful, landing 32 metric tons of halibut in its first season. Greenland's first shipyard was built in Sisimiut in 1931. These early developments, physically concentrated along the west shore of Sisimiut's harbor, placed the town at the forefront of Greenland fishing.

Overfishing by European longliners contributed to the disappearance of Atlantic halibut by the mid-1930s, forcing fishermen and the Sisimiut factory to seek other resources. The manager of the canning factory, Martin Hansen, recognized that shrimp provided one alternative. Four former halibut boats began fishing for shrimp in 1935, and the canning factory was converted accordingly (Smidt, 1989). Meanwhile, cod became even more important. "Everyone with a boat" could go fishing for the abundant cod during the late 1930s and 1940s. Motorized vessels towed dories offshore for jigging. Inshore, small boats fished with jigging wheels, or later cod traps and gillnets. It required a relatively large vessel like the Nakuak, however, to trawl for shrimp. Kleist and his crew began fishing for shrimp near Sisimiut in 1938, at a time when their neighbors did not yet see the value of this nontraditional resource "which are so tiny and we can't even live on them." Rich catches sold to the Sisimiut factory (or after 1950, to a new factory built at Qasigiannguit, nearer to the main Disko Bay shrimp banks) changed some minds, but the localized shrimp fishery was not on nearly the same scale as the cod fishery.

Two patterns visible in Sisimiut's nascent shrimp fishery foreshadow events in the later cod-to-shrimp transition. First, complex interactions occur among physical, biological, and social systems. Atlantic halibut, an early commercial target, was depleted by overfishing. Cod grew more abundant as their range extended northwards with Irminger water. From its beginnings, the shrimp fishery required greater capital investment (for both catching and processing) than the cod fishery. Shrimp also were concentrated in particular locations. Thus, for both economic and geographical reasons, shrimp fishing was not an option for everyone.

Second, social capital plays a role. Elements of foresight, cohesion, and political effectiveness (for example, by Kleist and his partners) help explain why Sisimiut, rather than some other northern settlement, so readily took advantage of shrimp resources. Other Sisimiut developmentsincluding not only the first private vessel (1928), but the processing plant (1924), shipyard (1931), and technical school (1948) — supported the new industry and paint a picture of an enterprising, politically connected town.

Paamiut, like Sisimiut, was an early site of commercial fishing. Trading began with the first wave of cod in 1917, and a building for salting cod was erected in 1920. Paamiut developed at a slower, more externally controlled pace than Sisimiut, however. Development accelerated after government planners in the late 1950s identified Paamiut as geographically ideal for industrial development because of its location in the open-water district and access to cod. The government made substantial investments in a new fish processing plant, where production began in 1967, and in large trawlers that could supply this plant with fish, beginning in the early 1970s (Rasmussen and Hamilton, 2001). For a time, Paamiut's plant was the largest in the North Atlantic. Around this cod industry, Paamiut was expected to grow through in-migration and become Greenland's second-largest settlement. Cod catches proved unpredictable, however, and the anticipated in-migration did not materialize.

Cod landings at Sisimiut varied between about 2000 and 5000 metric tons over most of the 1950s and 1960s. Landings fell sharply in 1968, and thereafter fluctuated erratically around a low average. By the late 1960s, northern fishing grounds, including those around Sisimiut, were feeling the effects of cod depletion and environmental change. Historically flexible, Sisimiut's fishing activity shifted towards shrimp and other species.

Paamiut cod landings had been comparable to Sisimiut's in the 1950s and 1960s, but subsequently peaked above 9000 metric tons per year in 1978-82 and passed 14000 metric tons in 1989-before falling to near zero, as cod utterly collapsed. The small quantities of shrimp found in neighboring fjords were not enough to replace cod, nor were there other resources suitable for large-scale industrial processing. With the cod collapse, Paamiut's overall landings value dropped precipitously. Meanwhile Sisimiut, now a shrimping center, maintained a high level of landings. Population growth in Sisimiut, and decline in Paamiut, reflected the fortunes of their divergent fisheries (Hamilton et al., 2000).

The 1988 map in Figure 7 shows known shrimp biomass concentrated north of Sisimiut, around Disko Bay. During the boom days of the shrimp fishery, Sisimiut built up catching and processing capacity. A production plant for peeled shrimp had been established in 1969, with a capacity of three metric tons per day. Investment in large freezer-trawlers in the early 1970s added at-sea processing as well as catching capacity. Shrimp landings in Sisimiut grew from under 1000 metric tons in 1975 to more than 8000 metric tons in 1988. Paamiut took little part in this boom. A small private company produced shrimp until 1971, but subsequent shrimp landings averaged only a few hundred metric tons per year, requiring limited processing capacity (Rasmussen and Hamilton, 2001).

Landings represent only a fraction of current West Greenland shrimp catches. In earlier times, the main product was peeled shrimp, which required processing and created employment on land. Nowadays, however, much of the catch is packed and frozen whole, aboard factory trawlers at sea. Whole frozen shrimp command higher prices, but their processing creates fewer jobs. In order to maintain some employment, the Home Rule government requires that at least $25 \%$ of the shrimp catch be landed and processed at onshore plants. Such landings provide one rough indication of how shrimp-fishery benefits are distributed among communities.

Figure 8 maps the reported catch locations of shrimp landed in Sisimiut in 1988 and 2000. The 1988 landings, 

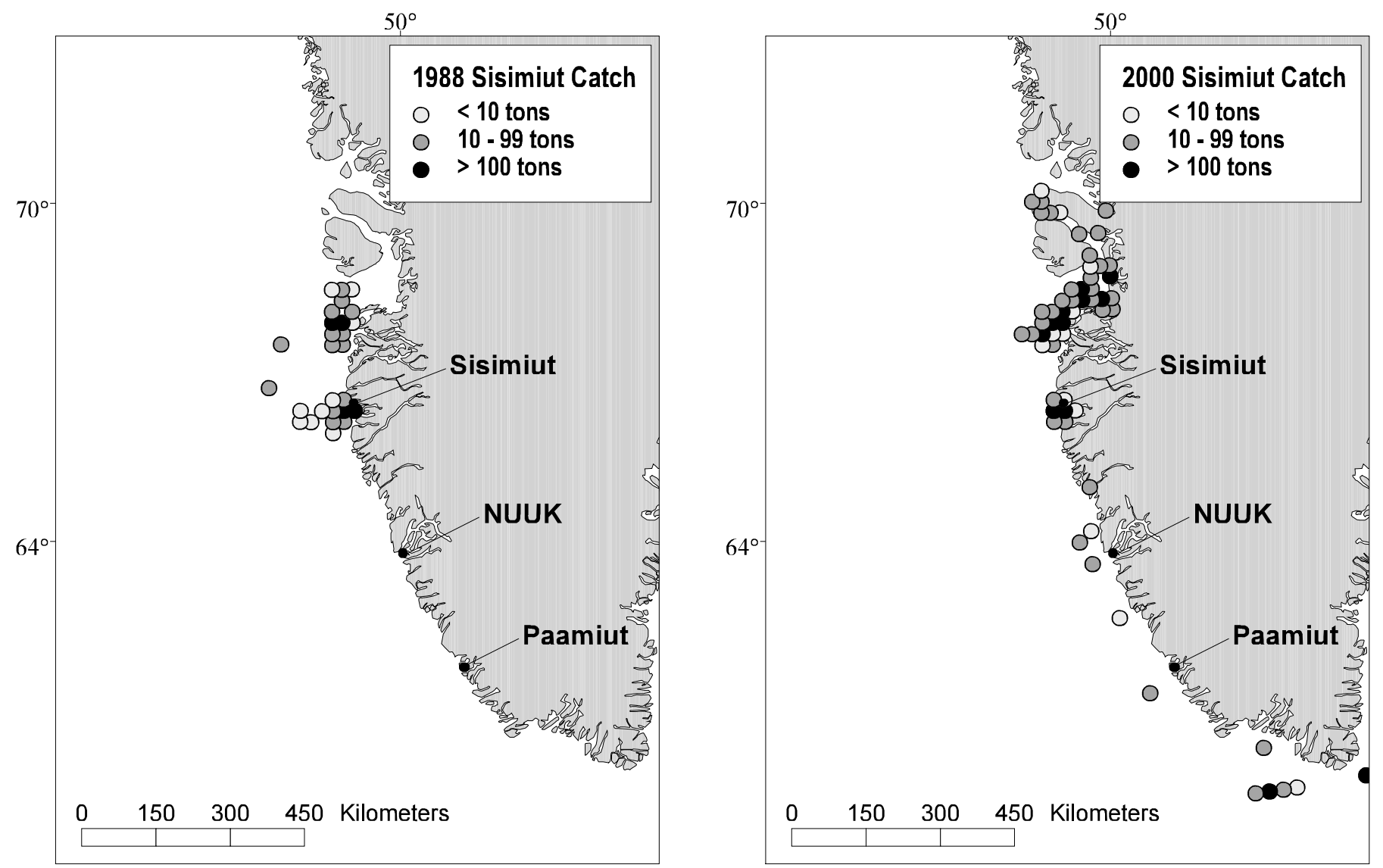

FIG. 8. Reported catch locations of shrimp landed in Sisimiut municipality, 1988 (left) and 2000 (right). Each circle represents the sum of landings caught within a $1 / 5^{\circ}$ latitude $\times 1 / 2^{\circ}$ longitude cell.

mainly by the inshore fleet of small trawlers, came from areas around Sisimiut and Disko Bay, that is, areas near the known concentrations of shrimp biomass (compare with Fig. 7). Catches supplying the 2000 landings likewise approximately follow the distribution of biomass, stretching southwards down the coast. The data on landings graphed in Figure 8 represent only a fraction of the total catches by Sisimiut vessels. Even among the reported landings, we mapped only those for which plausible catch locations were reported. The map gives an imperfect but useful representation of how Sisimiut's early dominance persisted even after its environmental advantage waned. Sisimiut was landing, and its workers were thus profiting from, shrimp caught all along the southwest coast. Large offshore trawlers registered in Sisimiut were even more wide-ranging, although their processed-at-sea catch does not show up in these landings data. In 1996, Sisimiut's medium- and large-vessel fleet totaled more than 4000 gross registered tons (Rasmussen and Hamilton, 2001).

Figure 9 maps the reported catch locations of shrimp landed in Paamiut for 1988 and 2000. Few shrimp were landed in 1988, all from local waters. Although greater concentrations of shrimp were known to exist offshore from Paamiut by 2000 (Fig. 7), these brought limited local benefit. The catching and processing capacity built up in Sisimiut and other ports during the growth days of the shrimp fishery allowed those ports to continue dominating the fishery even as catch locations extended farther south. In 1996, Paamiut's medium- and large-vessel fleet totaled only about 1000 gross registered tons, one-fourth that of Sisimiut (Rasmussen and Hamilton, 2001). Because other ports already had capacity to catch and process all the existing shrimp, there was no room for new investments in Paamiut.

In 1989, a new fishery for snow crab was organized in Nuuk. The resource proved too limited in Nuuk fjord, but more promising in the vicinity of Sisimiut. Sisimiut residents invited Canadian fishermen to teach them crab fishery techniques and began local manufacture of traps. Sisimiut became the center of this new fishery. Snow crab were found around Paamiut as well, but production there lagged behind that of Sisimiut, Aasiaat, and Nuuk until the government transferred a processing vessel (indhandlingsskib) to Paamiut in 2000. This vessel provided welcome economic activity, although it also conformed to the historical pattern of top-down development in Paamiut, contrasting with more local initiatives in Sisimiut.

Sisimiut and Paamiut are only two of the 14 municipalities of West Greenland. Their polar experiences during the cod-to-shrimp transition made them the focus of this analysis, although each other place has an interesting 

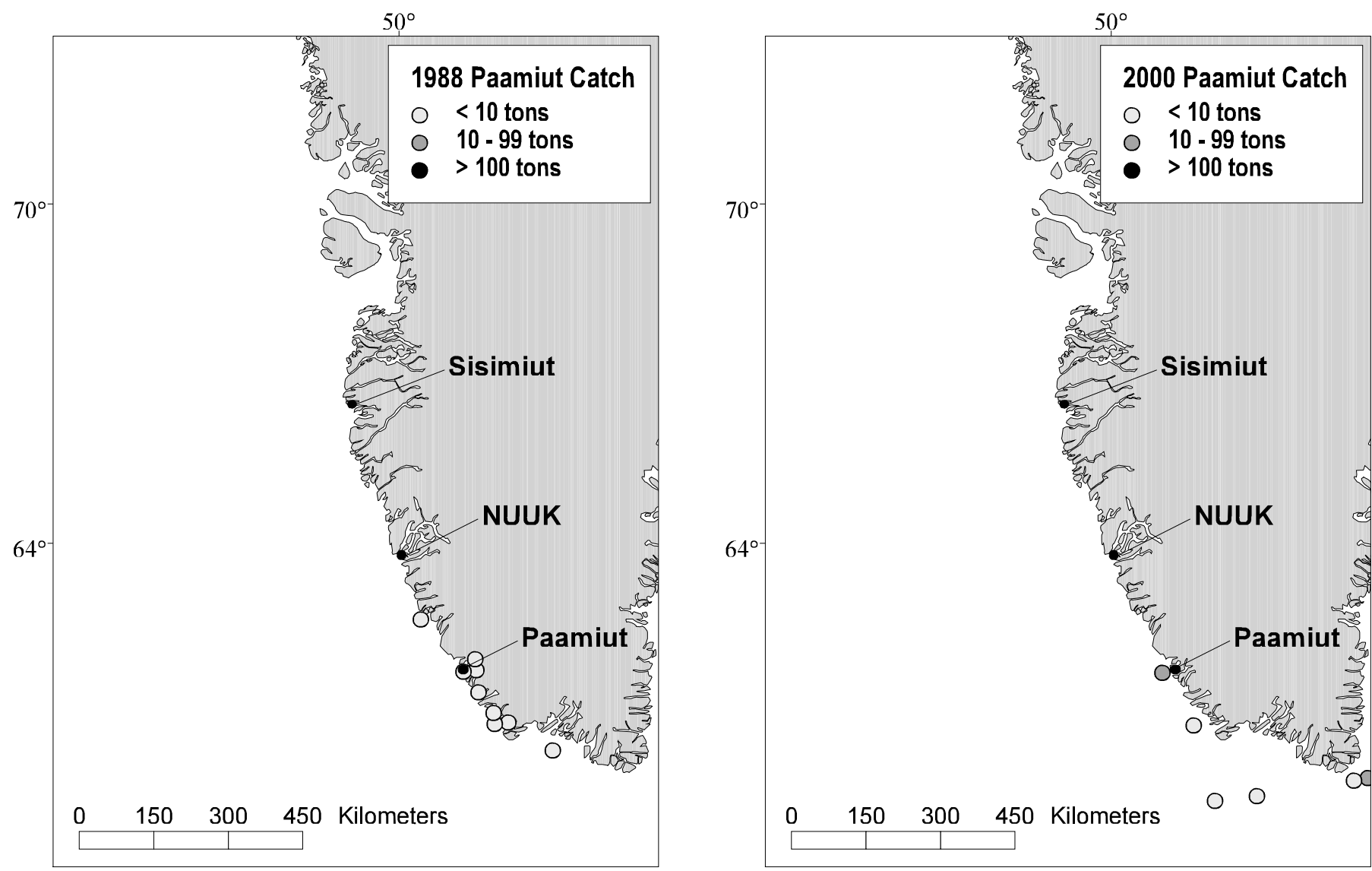

FIG. 9. Reported catch locations of shrimp landed in Paamiut municipality, 1988 (left) and 2000 (right). Each circle represents the sum of landings caught within a $1 / 5^{\circ}$ latitude $\times 1 / 2^{\circ}$ longitude cell.

story too. Data on the other municipalities appear in Hamilton et al. (2000).

\section{DISCUSSION}

Examining West Greenland's cod-to-shrimp transition, we followed links from large-scale climatic shifts through local ocean conditions, a marine ecosystem, and economic activity, and ultimately, to the fate of two coastal communities. This unique case study could have broader relevance in the 21 st century, as other societies face climatic change.

Greenland society, dependent on marine resources and living on the margins of an ice sheet, is exceptionally vulnerable to climatic change. This high-latitude environment did, in fact, experience some of the greatest climatic variations of the 20th century. Even so, we see that social forces filtered the human impacts of climatic variations. The divergent histories of Sisimiut and Paamiut show the characteristics of "path-dependent systems," in which outcomes relate stochastically to initial conditions and also depend upon factors that mediate between initial conditions and eventual outcomes (Goldstone, 1998). The initial conditions include natural resources, sometimes called "natural capital." The mediating factors can be character- ized as three other types of capital—physical, human, and social-that have importance for economic development.

Natural capital denotes environmental wealth such as resources, climate, and geography. Location conferred environmental advantages and disadvantages with respect to the shifting fish stocks. While cod were commercially important, Paamiut's natural-capital endowment encouraged government support for industrial development. As the transition to shrimp unfolded, however, Sisimiut's natural capital conferred new and unforeseen advantages. Differences in natural capital affected, but did not determine, the subsequent outcomes.

Physical capital investments, notably in shrimp processing and trawlers, channeled the distribution of benefits from environmental change. Communities where shrimpfishery investments were made early in the transition built more than enough capacity to capture the entire resource, leaving little justification for additional investments elsewhere. Sisimiut, close to the initial concentrations of shrimp, was the first to exploit this new resource, and built capacity to pursue it even as shrimp fishing extended southwards. But other northern settlements, also near the shrimp, did not necessarily do likewise. If we ask why those investments took place where they did, other factors come into view. 
Human capital involves skills and education. Sisimiut's historically more diverse economy supported a wider range of workforce skills than did Paamiut's concentration on cod fishing. Diversity proved to be an adaptive advantage, both for developing the new fishery and for sustaining other economic activities.

Social capital, the least tangible type, refers to social networks and norms of cooperation (Coleman, 1988). The enterprising spirit and social cohesion that enabled Elias Kleist and his partners to purchase Nakuak, the first private Greenlandic fishing vessel, appears in other episodes of Sisimiut history as well. It also comes up in some Greenlanders' accounts of the character of Sisimiut today. In contrast, the cod-industry development in Paamiut had been driven primarily by external initiatives, starting with plans from the main office of the Greenland Technical Organization (GTO) in Copenhagen to build a state-ofthe-art processing plant.

In both Sisimiut and Paamiut, government support for processing plants, trawlers, and other enterprises, which proved so important, also reflected differences in social capital. In Paamiut there was limited social contact between the local community and the institutional framework behind the decision process, whereas in Sisimiut connections were stronger. Government decisions are influenced by family networks that tie political leaders to their home communities. Sisimiut's representatives have been notably effective: "They are not sleeping," as residents approvingly remark.

Climatic change increased the salience of differences in natural, physical, human, and social capital. Sisimiut's natural capital (nearby shrimp) conferred one early advantage, but its ability to exploit that advantage resulted from an adaptive capacity afforded by its particular blend of physical, human, and social capital. That Sisimiut would prosper during the cod-to-shrimp transition was by no means assured, but rather emerged from the interactions among various types of capital-in a path-dependent fashion.

From this West Greenland case study, we suggest two general propositions about the human dimensions of climatic change. First, socially important environmental changes result not simply from climatic change, but from interactions between climate, ecosystem, and resource usage. For example, resource exploitation that is near its sustainable limits could rapidly become unsustainable when a less favorable climate reduces those limits (see Amorosi et al., 1997, for parallel observations about the medieval North Atlantic). Second, environmental changes affect people differentially through interactions with social factors. Social networks and cohesion (social capital), as well as skills (human capital), investments (physical capital), and alternative resources (natural capital), shape how the benefits and costs are distributed.

\section{ACKNOWLEDGEMENTS}

The North Atlantic Arc (NAArc) research project has been supported by grants from the Arctic System Science and Arctic Social Sciences programs of the U.S. National Science Foundation (OPP-9515380 and OPP-9912004). Per Kanneworff (Greenland Institute of Natural Resources), Erik Buch (Danish Meteorological Institute), Ole Folmer (Danish Fisheries Institute), and Nathan Larsen (Sisimiut Museum) generously shared their data with the authors. We also benefited from discussions with Birger Poppel (Statistics Greenland), Klaus Georg Hansen (Sisimiut Museum), Per Lyster Pedersen (Asiaq), and Helle Siegstad, Dan Carlsson, and Kai Wieland (Greenland Institute of Natural Resources), as well as from suggestions by anonymous reviewers. The opinions (and, of course, any errors in this paper) are the authors' own. An earlier version of this paper was presented at the 32nd Annual Arctic Workshop, Institute of Arctic and Alpine Research (INSTAAR), held in Boulder, Colorado, on 14-16 March 2002.

\section{REFERENCES}

AMOROSI, T., BUCKLAND, P., DUGMORE, A., INGIMUNDARSON, J.H., and McGOVERN, T.H. 1997.

Raiding the landscape: Human impact in the Scandinavian North Atlantic. Human Ecology 25(3):491-518.

ARNASON, R., and FELT, L.F., eds. 1995. The North Atlantic fishery: Strengths, weaknesses, and challenges. Charlottetown, PEI: Institute of Island Studies.

BELKIN, I.M. 2000. Decadal variability of the Greenland Ice Sheet mass balance as a cause of salinity-ice-temperature anomalies in the North Atlantic. Paper presented at the 30th Annual Arctic Workshop, 16-18 March, Boulder, Colorado.

BELKIN, I.M., LEVITUS, S., ANTONOV, J., and MALMBERG, S.-A. 1998. 'Great salinity anomalies' in the North Atlantic. Progress in Oceanography 41:1-68.

BERENBOIM, V.I., DOLGOV, A.V., KORZHEV, V.A., and YARAGINA, N.A. 2000. The impact of cod on the dynamics of Barents Sea shrimp (Pandalus borealis) as determined by multispecies models. Journal of Northwest Atlantic Fisheries Science 27:69-76.

BLUNIER, T., and BROOK, E.J. 2001. Timing of millennial-scale climate change in Antarctica and Greenland during the last glacial period. Science 291(5501):109-112.

BOREMAN, J., NAKASHIMA, B.S., WILSON, J.A., and KENDALL, R.L., eds. 1997. Northwest Atlantic groundfish: Perspectives on a fishery in collapse. Bethesda, Maryland: American Fisheries Society.

BOROVKOV, V.A., and STEIN, M. 2001. Recruitment of West Greenland cod-Modelling different cause-effect regimes. NAFO SCR Doc. 01/7.

BROECKER, W.C. 1997. Thermohaline circulation, the Achilles heel of our climate system: Will man-made $\mathrm{CO}_{2}$ upset the current balance? Science 278:1582-1588. 
BUCH, E. 2000a. A monograph on the physical oceanography of the Greenland waters. Scientific Report 00-12. Copenhagen: Danish Meteorological Institute.

2000b. Air-sea-ice conditions off southwest Greenland, 1981-97. Journal of Northwest Atlantic Fishery Science 26: $1-14$.

BUCH, E., and HANSEN, H.H. 1988. Climate and cod fishery at West Greenland. In: Wyatt, T., and Larrañeta, M.G., eds. Longterm changes in marine fish populations. Vigo, Spain: Instituto Investigaciones Marinas. 345-364.

BUCH, E., PEDERSEN, S.A., and NIELSEN, M.H. 2001. On the coupling between climate, hydrography and recruitment variability of fishery resources off West Greenland. International Council for the Exploration of the Sea (ICES) Decadal Symposium, 8-10 August, Edinburgh.

CARLSSON, D.M., and KANNEWORFF, P. 2000. Stratifiedrandom trawl survey for northern shrimp (Pandalus borealis) in NAFO Subareas 0+1, in 2000. NAFO SCR Doc. 00/78.

COLEMAN, J.C. 1988. Social capital in the creation of human capital. American Journal of Sociology 94:S95-S120.

DICKSON, R.R., MEINCKE, J., MALMBERG, S.-A., and LEE, A.J. 1988. The 'Great Salinity Anomaly' in the northern North Atlantic 1968-82. Progress in Oceanography 20:103-151.

DICKSON, R.R., LAZIER, J.R.N., MEINCKE, J., RHINES, P., and SWIFT, J. 1996. Long-term coordinated changes in the convective activity of the North Atlantic. Progress in Oceanography 38:241-295.

GANOPOLSKI, A., and RAHMSTORF, S. 2000. Rapid changes of glacial climate simulated in a coupled climate model. Nature 409(11 January):153-158.

GOLDSTONE, J.A. 1998. Initial conditions, general laws, path dependence, and explanation in historical sociology. American Journal of Sociology 104(3):829-845.

HAMILTON, L.C., and BUTLER, M.J. 2001. Outport adaptations: Social indicators through Newfoundland's cod crisis. Human Ecology Review 8(2):1-11.

HAMILTON, L.C., and HAEDRICH, R.L. 1999. Ecological and population changes in fishing communities of the North Atlantic Arc. Polar Research 18(2):383-388.

HAMILTON, L.C., LYSTER, P., and OTTERSTAD, O. 2000. Social change, ecology and climate in 20th century Greenland. Climatic Change 47(1/2):193-211.

HANNESSSON, R. 1996. Fisheries mismanagement: The case of the North Atlantic cod. Oxford: Fishing News Books.

HILMER, M., HARDER, M., and LEMKE, P. 1998. Sea ice transport: A highly variable link between Arctic and North Atlantic. Geophysical Research Letters 25(17):3359-3362.

HORSTED, S.A. 2000. A review of the cod fisheries at Greenland, 1910-1995. Journal of Northwest Atlantic Fisheries Science 28.

HURRELL, J.W. 1995. Decadal trends in the North Atlantic Oscillation regional temperatures and precipitation. Science 269:676-679.

HURRELL, J.W., and VAN LOON, H. 1997. Decadal variations in climate associated with the North Atlantic Oscillation. Climatic Change 36:301-326.
HURRELL, J.W., KUSHNIR, Y., and VISBECK, M. 2001. The North Atlantic Oscillation. Science 291(5504):603-605.

HVINGEL, C. 1999a. The fishery for northern shrimp (Pandalus borealis) off West Greenland, 1970-1999. NAFO SCR Doc. 99/107.

. 1999b. The fishery for northern shrimp (Pandalus borealis) off East Greenland, Greenlandic Zone, 1987-1999. NAFO SCR Doc. 99/108.

HVINGEL, C., LASSEN, H., and PARSONS, D.G. 2000. A biomass index for northern shrimp (Pandalus borealis) in Davis Strait based on multiplicative modelling of commercial catch-perunit-effort data (1976-97). Journal of Northwest Atlantic Fisheries Science 26:25-36.

JACKSON, J.B.C., KIRBY, M.X., BERGER, W.H., BJORNDAL, K.A., BOTSFORD, L.W., BOURQUE, B.J., BRADBURY, R.H., COOKE, R., ERLANDSON, J., ESTES, J.A., HUGHES, T.P., KIDWELL, S., LANGE, C.B., LENIHAN, H.S., PANDOLFI, J.M., PETERSON, C.H., STENECK, R.S., TEGNER, M.J., and WARNER. R.R. 2001. Historical overfishing and the recent collapse of coastal ecosystems. Science 293(5530):629-638.

JAKOBSSON, J., ASTTHORSSON, O.S., BEVERTON, R.J.H., BJÖRNSSON, N., DAAN, N., FRANK, K.T., MEINCKE, J., ROTHSCHILD, B., SUNDBY, S., and TILSETH, S., eds. 1994. Cod and climate change. Proceedings of a Symposium held in Reykjavík. Copenhagen: International Council for the Exploration of the Sea (ICES).

LANGENBERG, H. 2000. Oscillating opinion. Nature 408(21/28 December):924-925.

MANABE, S. 1995. Simulation of abrupt climate change induced by freshwater input to the North Atlantic Ocean. Nature 378(6553): $165-167$.

MARQUARDT, O., HOLM, P., and STARKEY, D.J., eds. 1999. From sealing to fishing: Essays on social and economic change in Greenland, 1850-1940. Esbjerg, Denmark: Fiskeri-og Søfartsmuseets Forlag.

MATTOX, W.G. 1973. Fishing in West Greenland 1910-1966: The development of a new native industry. Copenhagen: Meddelelser om Grønland 197(1).

MAYEWSKI, P.A., MEEKER, L.D., WHITLOW, S.I., TWICKLER, M.S., MORRISON, M.C., BLOOMFIELD, P., BOND, G.C., ALLEY, R.B., GOW, A.J., GROOTES, P.M., MEESE, D.A., RAM, M., TAYLOR, K.C., and WUMKES, W. 1994. Changes in atmospheric circulation and ocean ice cover over the North Atlantic during the last 41,000 years. Science 263:1747-1751.

MORISON, J., AAGAARD, K., and STEELE, M. 2000. Recent environmental changes in the Arctic: A review. Arctic 53(4): $359-371$

MORISON, J., ALEXANDER, V., CODISPOTI, L., DELWORTH, T., DICKSON, B., EICKEN, H., GREBMEIER, J., KRUSE, J., OVERLAND, J., OVERPECK, J., SCHLOSSER, P., SERREZE, M., and WALSH, J. 2001. SEARCH: Study of Environmental Arctic Change, Science Plan. Seattle: Applied Physics Laboratory, University of Washington. 
NAFO (NORTHWEST ATLANTIC FISHERIES ORGANIZATION). 2002. Fisheries statistics web site. http:// www.nafo.ca

PAULY, D., CHRISTENSEN, V., DALSGAARD, J., FROESE, R., and TORRES, F., Jr. 1998. Fishing down marine food webs. Science 279:860-863.

RASMUSSEN, R.O., and HAMILTON, L.C. 2001. The development of fisheries in Greenland, with focus on Paamiut/ Frederikshåb and Sisimiut/Holsteinsborg. Roskilde, Denmark: North Atlantic Regional Studies.

RÄTZ, H.-J. 1992. Decrease in fish biomass off West Greenland (subdivisions 1B-1F). NAFO SCR Doc 92/40.

—_. 1999. Structures and changes of the demersal fish assemblage off Greenland, 1982-96. NAFO SCR 32:1-15.

SCHMUTZ, C., LUTERBACHER, J., GYALISTRAS, D., XOPLAKI, E., and WANNER, H. 2000. Can we trust proxybased NAO index reconstructions? Geophysical Research Letters 27(8):1135-1138.

SERREZE, M.C., WALSH, J.E., CHAPIN, F.S., III, OSTERKAMP, T., DYURGEROV, M., ROMANOVSKY, V., OECHEL, W.C., MORISON, J., ZHANG, T., and BARRY, R.G. 2000.
Observational evidence of recent change in the northern highlatitude environment. Climatic Change 46:159-200.

SIEGSTAD, H. 2000. Preliminary assessment of shrimp (Pandalus borealis) in Davis Strait, 2000 (Subareas 0+1). NAFO SCR Doc 00/84.

SMIDT, E.L.B. 1989. Min tid i Grønland — Grønland i min tid (My time in Greenland - Greenland in my time). Fiskeri, Biologi, Samfund 1948 - 1985. Copenhagen: Nyt Nordisk Forlag Arnold Busck.

STATISTICS GREENLAND. 2000. Greenland 2000-2001: Statistical Yearbook. Nuuk: Greenland Home Rule Government.

TURRELL, B., and HOLLIDAY, P., eds. 2001. The annual ICES ocean climate status report 2000/2001. Copenhagen: International Council for the Exploration of the Sea.

VILHJÁLMSSON, H. 1997. Climatic variations and some examples of their effects on the marine ecology of Icelandic and Greenland waters, in particular during the present century. Journal of the Marine Research Institute 15(1):9-29.

WORM, B., and MYERS, R.A. 2003. Top-down versus bottom-up control in oceanic food webs: A meta-analysis of cod-shrimp interactions in the North Atlantic. Ecology 84:162-173. 